\title{
FACTORS INFLUENCING THE ATTACK RATE OF PULMONARY TUBERCULOSIS
}

\author{
BY \\ A. L. COCHRANE, T. FRANCIS JARMAN, AND W. E. MIALL \\ WITH THE ASSISTANCE OF R. G. CARPENTER \\ From the Pneumoconiosis Research Unit of the Medical Research Council, Llandough Hospital, near Cardiff, and \\ the Mass Radiography Service, Welsh Regional Hospital Board
}

(RECEIVED FOR PUBLICATION NOVEMBER 17,1955 )

The most useful knowledge when attempting to prevent a chronic disease is that of the factors influencing its attack rate. A knowledge of the factors relating to mortality rates and prevalence rates is less valuable for this purpose, as both are secondary indices, mortality varying directly with attack rate and case fatality rate, and prevalence varying directly with the attack rate and indirectly with the case fatality rate. It is therefore regrettable that the attack rate of tuberculosis has been so little studied in comparison with the vast literature on mortality. Such studies as have been published have been summarized in the Prophit Report (Daniels, Ridehalgh, Springett, and Hall, 1948). This work consisted mainly of follow-up studies on medical students and nurses, and the results of studies on such selected material are unlikely to be generally applicable. The only study of the attack rate of tuberculosis in the general population is that of Springett (1951) which, in spite of its general excellence, can be criticized on the grounds that the population on which the attack rate was studied was somewhat ill defined. It therefore seemed of value to see what information could be obtained on this point from the material obtained from the two Rhondda Fach surveys (Cochrane, Cox, and Jarman, 1952, 1955).

\section{Material AND Techniques}

The population of the Rhondda Fach, a relatively isolated Welsh mining valley, was radiographed in $1950-51$ and again in 1953 (an interval of 2.6 years). The techniques used and the general results have already been described (Cochrane and others, 1952, 1955).

In this paper we are chiefly concerned with that aspect of the survey which involved the "follow-up" of those radiographed in 1950-51. The people living in the valley in 1950 fell into four groups at the time of the 1953 survey: (a) those who were radiographed again; (b) those who, although still living in the area, refused or were unable to be radiographed again; (c) those who had left the area; and $(d)$ those who had died. Figs. 1, 2, and 3 , one of which has been previously published, show the proportions of various categories of the population whom we were able to re-examine. We were able to radiograph again $95 \%$ of those still available in the valley. Although the follow-up rate is, in general, satisfactory, it is unfortunate that in the males it should be particularly low in the 15-24 age group. As can be seen from the diagrams, this is due to the high percentage who left the area. This is, in turn, associated with the call-up for military service.

The follow-up of those who were not radiographed in 1950-51 is also of interest (Figs. 4 and 5). The fact that nearly $50 \%$ of those who refused on the first occasion accepted on the second is of considerable importance, particularly as we have been able to confirm the existence of this phenomenon in some of our other work. It suggests that very high percentages of populations might be radiographed if survey teams returned after relatively short intervals.

\section{RESULTS}

The Effect of Age and Sex.-Our results for the attack rate of tuberculosis on the women and non-miners are shown in Table I and Fig. 6, where they are compared with those of Springett (1951) - the only possible source of comparison. In general, the agreement is good. In particular, our results confirm the low attack rate in the higher age groups of the males. It must, however, be emphasized that our population contains very few non-miners in the higher age groups.

The actual size of our attack rates appears high - particularly in relation to the thoroughness of 


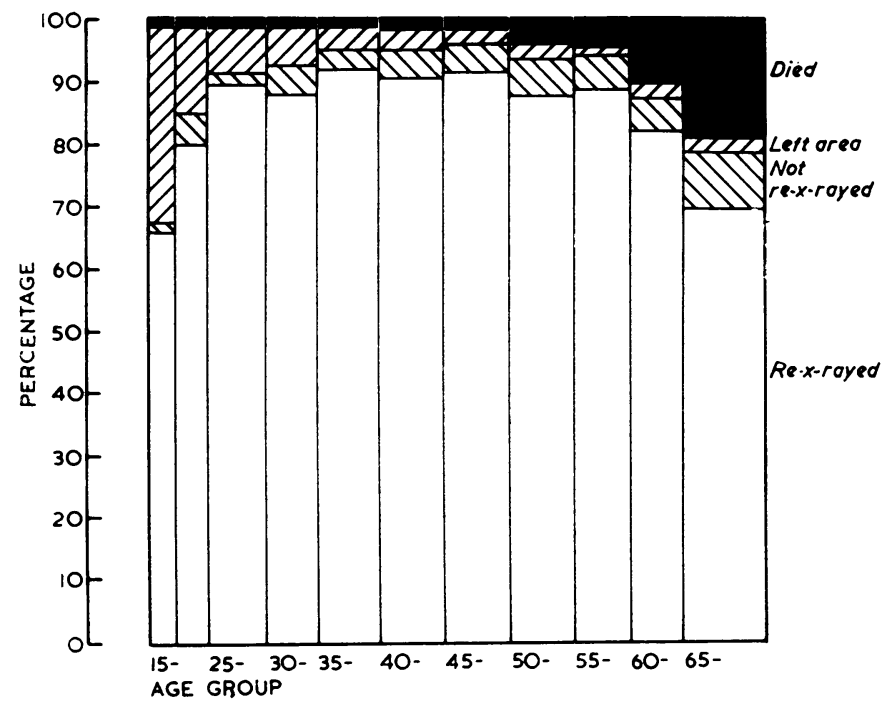

FIG. 1.-Details of follow-up of 6,140 miners and ex-miners radiographed in 1950 51 in relation to the second radiological survey in 1953. The area of each age group column is proportional to the numbers of individuals in it. make any definite allowance for this factor, but we can do this for another factor, "contact" with known infectious cases.

The EfFect of Contact with INFECTIOUS CASES.-Where special efforts have been made to identify the infectious cases in a small area like the R.hondda Fach, it is possibly too easy to relate the occurrence of a new case to some contact with a previously known infectious case. We have therefore adopted another technique and started with the infectious cases, defining as " contacts" only their relatives living in the house and their most intimate friends, an average of four or five contacts per case.

The results are shown in Table II for females and non-mining males and in Fig. 7 for females. As one would expect, the attack rate is higher amongst the contacts. There are, however, several

the 1950-51 survey and the rapid admission to hospital oi the active cases. It has, however, been pointed out in a previous publication (Cochrane and others, 1955) that the figures are not really comparable with those of Springett. We included as " new cases" all those who, after detailed clinical examination, were accepted by the chest clinic as pulmonary tuberculosis. This included cases of pleurisy and of uncomplicated primary type tuberculosis. Springett (personal communication, 1954) did not include either of these types in his series, and if allowance for this is made the figures for the Rhondda Fach are much lower than Springett's (Cochrane and others, 1955).

The relative size of the male and female attack rates in our survey is also different from that in Springett's. The attack rate is affected by factors other than age and sex, and these must also be

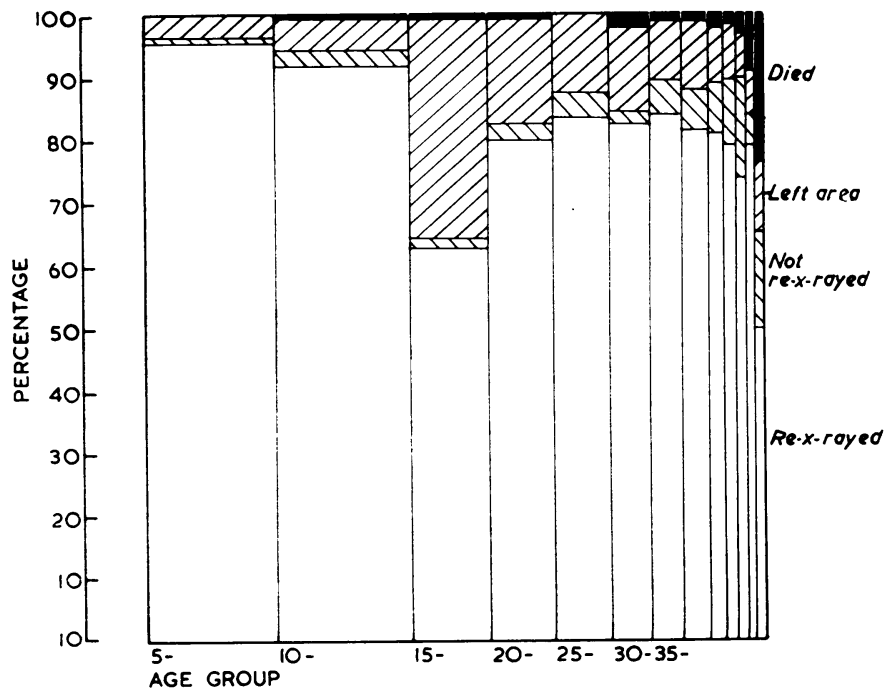

FIG. 2.-Details of follow-up of 4,310 non-mining males radiographed in 1950-51 in relation to the second radiological survey in 1953 . The area of each age group column is proportional to the numbers of individuals in it.

considered. He have already referred to the poor follow-up in the 15-19 and 20-24 age groups in the non-miners $(62.5 \%$ and $80.1 \%)$ chiefly owing to the call-up for the armed Services. As those who had already developed tuberculosis would not be accepted for the Forces, our survivors are already a selected group, and the real attack rate may have been considerably smaller. We have been unable to additional points worthy of comment. In all the cases whose occurrence was related to a known case the radiological evidence of disease appeared after the contact had been broken by admission to hospital of the infectious case. None of the cases could be related to an old lady who refused to be admitted to hospital or to the patients who discharged themselves from hospital when still infectious. 


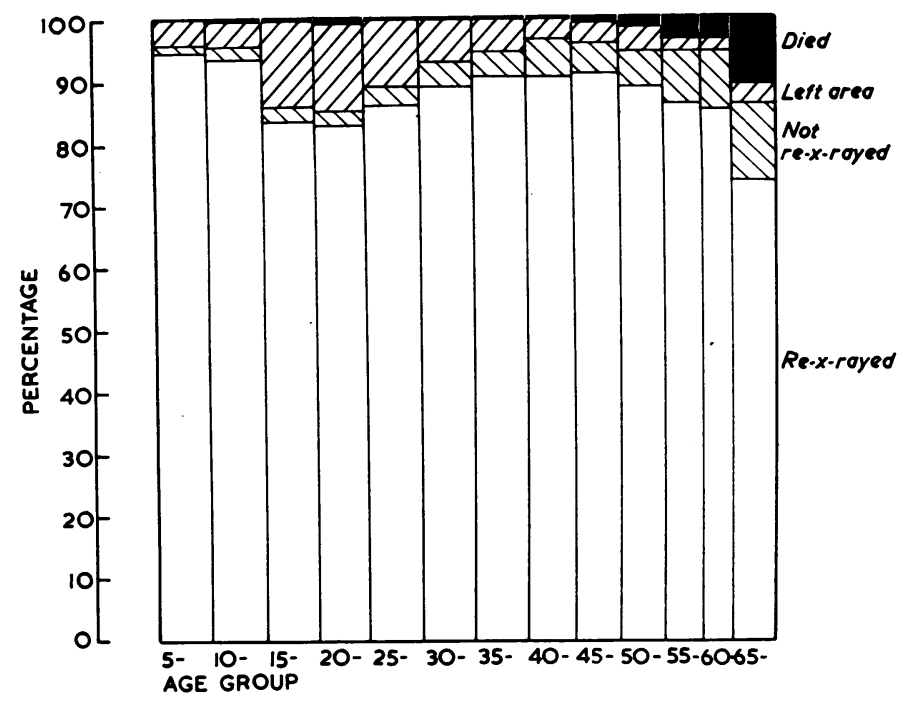

FIG. 3.-Details of follow-up of 10,618 females radiogra phed in 1950-51 in relation to the second radiological survey in 1953. The area of each age group column is proportional to the numbers of individuals in it. outside the valley as to work inside. The effect is apparent but less marked in the males.

At this point it is convenient to consider the relative importance of age, contact, place of work, and sex. Springett (1951) demonstrated how the attack rate of tuberculosis in both sexes was related to age, and a glance at our data confirms this, so no statistical analysis is necessary to prove it. The remaining three factors were therefore investigated within the three age groups 5-14, 15-24, and 25-34. Each of these factors may be interrelated, and each factor may vary in importance from age group to age group. Thus, for example, it might be that more young women who work outside the valley were contacts within the valley than those who work inside the valley. Thus the lower half of Fig. 7 might in fact be
The new cases for which no contact was found may, in general, be explained in three ways:

(1) The arbitrary threshold used in our definition of contact may have excluded some new cases infected by known cases in the valley.

(2) Some of the cases had close contact with infectious cases outside the valley (discussed below).

(3) In a few new cases where we could not discover any contact with known infectious persons, there was very close contact with a case of progressive massive fibrosis (P.M.F.), whose sputum was negative. It seems to us possible that some patients with P.M.F. may intermittently excrete a few tubercle bacilli which, over a period of time, are sufficient to produce infection in a close contact. This point has been investigated and will be published in due course.

One method of determining whether we have been successful in reducing the infectivity of the Rhondda Fach below the average of the areas surrounding it is to compare the attack rate amongst those who live and work in the valley with that of those who live in the valley but work outside it.

This comparison is shown in Table III and Fig. 7 and appears to be important. In females it appears to have been nearly five times as dangerous to work

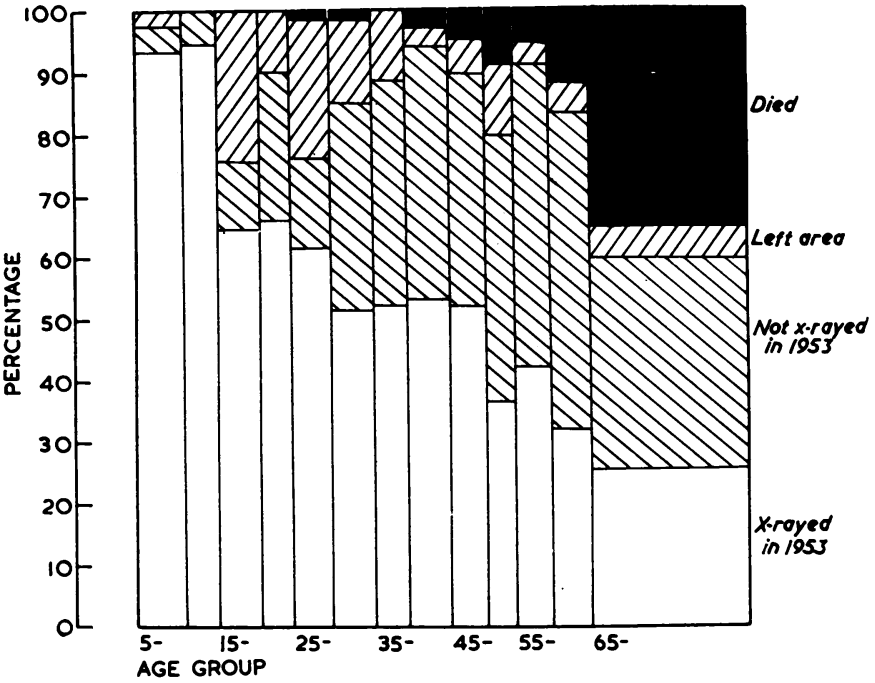

FIG. 4-Details of follow-up of 962 males not radiographed in 1950-51, in relation to the radiological survey of 1953 . The area of each age group column is proportional to the number of individuals in it.

merely a reflection of the top half. A study of the data does not lead us to this conclusion, but a statistical analysis should take account of this possibility. A weighted regression analysis was therefore carried out on a transformation of the percentage of attacks. This was done within age groups and using history of contact, place of work, and sex as the predetermined variables. 


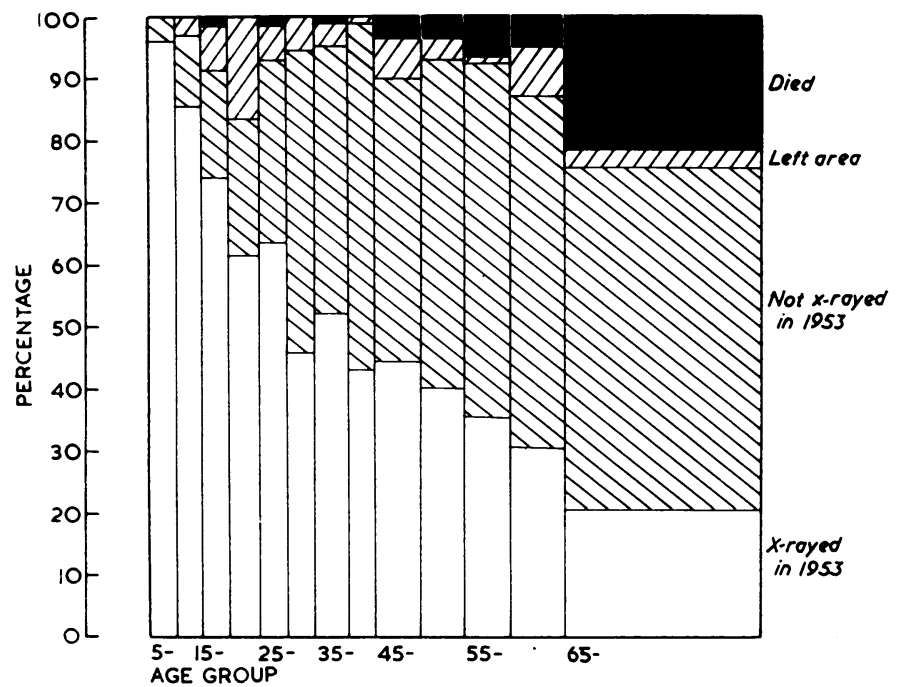

FIG. 5.-Details of follow-up of 1,582 females not radiographed in 1950-51, in relation to the radiological survey of 1953. The area of each age group column is proportional to the numbers of individuals in it.

TA.BLE I

ANNUAL ATTACK RATES OF PULMONARY TUBERCULOSIS AMONGST FEMALES AND NON-MINING MALES IN THE RHONDDA FACH, 1950 51-1953, COMPARED WITH ATTACK RATES AMONGST CIVIL SERVANTS IN LONDON, 1946-1948 (SPRINGETT, 1951)

\begin{tabular}{|c|c|c|c|c|c|c|c|c|}
\hline \multirow{3}{*}{ Age } & \multicolumn{4}{|c|}{ Females } & \multicolumn{4}{|c|}{ Non-mining Males } \\
\hline & \multirow{2}{*}{ No. } & \multirow{2}{*}{ 它冚 } & \multicolumn{2}{|c|}{$\begin{array}{l}\text { Annual Attack } \\
\text { Rate of Tuber- } \\
\text { culosis per } 1,000\end{array}$} & \multirow{2}{*}{ No. } & \multirow{2}{*}{ 它异 } & \multicolumn{2}{|c|}{$\begin{array}{l}\text { Annual Attack } \\
\text { Rate of Tuber- } \\
\text { culosis per } 1,000\end{array}$} \\
\hline & & & $\begin{array}{l}\text { Our } \\
\text { Data }\end{array}$ & $\begin{array}{l}\text { Springett's } \\
\text { Data }\end{array}$ & & & $\begin{array}{l}\text { Our } \\
\text { Data }\end{array}$ & $\begin{array}{c}\text { Springett's } \\
\text { Data }\end{array}$ \\
\hline $5-$ & 1,744 & 8 & 1.7 & & 1,725 & 4 & 0.9 & \\
\hline $15-$ & 1,365 & 10 & 28 & 35 & 683 & 12 & $6 \cdot 8$ & $3 \cdot 0$ \\
\hline $\begin{array}{l}25- \\
35-\end{array}$ & $\begin{array}{r}1,600 \\
1,536\end{array}$ & 3 & 0.7 & 20 & 543 & 3 & $2 \cdot 1$ & 20 \\
\hline $\begin{array}{l}45- \\
55- \\
65-\end{array}$ & $\begin{array}{r}1,392 \\
977 \\
554\end{array}$ & 1 & $0 \cdot 3$ & 0.5 & $\begin{array}{r}150 \\
96 \\
36\end{array}$ & & & $1 \cdot 0$ \\
\hline Total & 9,168 & 22 & 09 & & 3,562 & 19 & $2 \cdot 0$ & \\
\hline
\end{tabular}

The results of this analysis are as follows. There is no evidence that the effects of the factors contact, place of work, or sex differed between the three age groups. Both a history of contact and of working outside the valley appeared independently as significant factors increasing the attack rate (for both $\mathrm{P}<0.01$ ).

In contrast, we find that after considering the first two factors the effect of sex is negligible. The reason for the higher attack rate of tuberculosis in non-miners compared with women, shown in Fig. 6, is now clear. An inspection of Tables II and III shows that a slightly higher proportion of nonminers had histories of contact and also a very much higher proportion of them were working outside the valley.

OVERCROWDING.-The work of Stein (1952 and 1954) and others has drawn $\overparen{D}$ attention to the close correlation between overcrowding and the notification and mortality rates for tuberculosis,. particularly in Scotland. Table IV gives $\overrightarrow{\vec{\omega}}$ the Registrar General's overcrowding $\stackrel{\omega}{\sigma}$ indices (General Register Office, 1954) $\underset{x}{\vec{x}}$ for the Rhondda Urban District, together with the same indices for other $\vec{i}$ representative areas. The satisfactory situation in the Rhondda is partly due $\stackrel{\oplus}{\nexists}$ to the fact that its population fell con- 응 siderably between 1930 and 1950 .

Although both indices are so much $c$ lower in the Rhondda than in the Scottish areas where the most important correlations between tuberculosis and $\mathcal{G}$ such indices have been found, it seemed worth while seeing whether there were still any correlations at this lower level of overcrowding, especially as the radiological attack rate should be a much more sensitive index than notification rates or mortality ra'es. The details about the homes of the cases attacked by tuberculosis were obtained at the time of diagnosis. Later, an age-sex matched control group was chosen at random from the rest of the population in the area, and the overcrowding details obtained by home visiting. The results are shown in Table V. The differences are not statistically significant.

RELATIONSHIP BETWEen Radiological ATtaCK Rate and Results of Mantoux Testing at First 8 SURVEY.- The results are shown in Table VI. The literature on this subject was very extensively 을 reviewed in the Prophit Report (Daniels and others, 1948). At that time very nearly all observers had shown that the attack rate was higher in those who were previously Mantoux negative than in or those who were Mantoux positive, as confirmed by O the Prophit Report itself. The only contrary $\mathbb{W}^{-}$ observations at that time were from a group of $\bar{\sigma}$ American workers (Myers and Harrington, 1934; Pope, Sartwell, and Zacks, 1939; Stewart, 1940). The authors of the Prophit Report interpreted this $\stackrel{\mathcal{D}}{+}$ discrepancy as due to the low tuberculous infectivity 0 of the areas investigated in America. Theoretically, when tuberculous infectivity approaches zero the $\stackrel{\mathbb{D}}{\Omega}$ attack rate on Mantoux-negative children will be $\overrightarrow{\mathbb{D}}$ zero before that on Mantoux-positive children, as conversion of the Mantoux test to positive is known to precede radiological evidence of tuberculosis. 

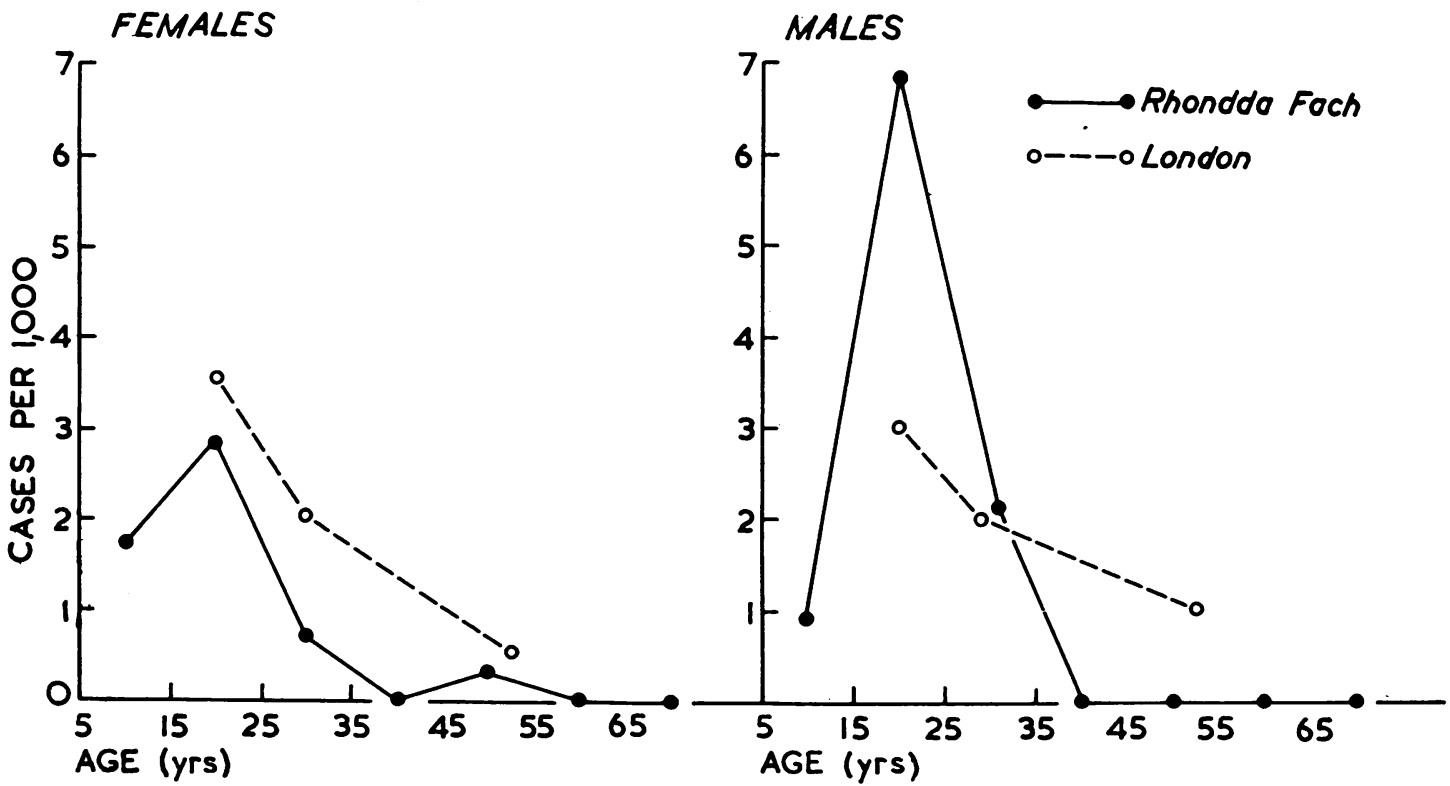

Fig. 6.-Comparison between the annual attack rates of pulmonary tuberculosis among the non-mining population of the Rhondda Fach, 1950-51, and among civil servants in London, 1946-48. The left half of the figure refers to females in the Rhondda and London and the right half to non-mining males in the Rhondda Fach and male civil servants in London.

The most recent work in this field is that of Palmer and Shaw (1953), who, in the course of their B.C.G. studies, found a much higher attack rate of tuberculosis amongst those initially tuberculin-positive than amongst those initially tuberculin-negative. B.C.G. vaccination had, at the time of their preliminary report, made very little difference. The groups studied included American Indian and Puerto Rican children, so it is improbable that low infectivity is the only explanation.

The difference between the two attack rates in our series is not statistically significant $(0.2>\mathrm{P}>0.1)$, but the trend is in fact similar to that of the American workers.

TABLE II

RELATIONSHIP BETWEEN CONTACT AND ATTACK RATE OF TUBERCULOSIS AMONGST WOMEN AND NON-MINERS IN THE RHONDDA FACH

\begin{tabular}{|c|c|c|c|c|c|c|c|}
\hline & \multirow[b]{2}{*}{ Age } & \multicolumn{3}{|c|}{ Contacts } & \multicolumn{3}{|c|}{ Non-contacts } \\
\hline & & No. & 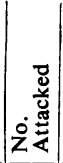 & 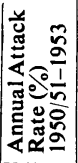 & No. & Z总 & 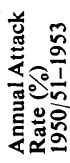 \\
\hline Women & $\begin{array}{r}5-14 \\
15-24 \\
25-34\end{array}$ & $\begin{array}{l}49 \\
53 \\
41\end{array}$ & $\begin{array}{l}2 \\
2 \\
1\end{array}$ & $\begin{array}{l}1.6 \\
1.5 \\
0.9\end{array}$ & $\begin{array}{l}1,694 \\
1,311 \\
1,559\end{array}$ & $\begin{array}{l}6 \\
8 \\
2\end{array}$ & $\begin{array}{l}0 \cdot 1 \\
0 \cdot 2 \\
0.05\end{array}$ \\
\hline $\begin{array}{l}\text { Non-miners who } \\
\text { remained non- } \\
\text { miners } 1950-53\end{array}$ & $\begin{array}{r}5-14 \\
15-24 \\
25-34\end{array}$ & $\begin{array}{l}51 \\
25 \\
10\end{array}$ & $\begin{array}{l}1 \\
4 \\
1\end{array}$ & $\begin{array}{l}0 \cdot 8 \\
6 \cdot 2 \\
3 \cdot 8\end{array}$ & $\begin{array}{r}1,542 \\
559 \\
515\end{array}$ & $\begin{array}{l}3 \\
8 \\
2\end{array}$ & $\begin{array}{l}0 \cdot 1 \\
0 \cdot 6 \\
0 \cdot 1\end{array}$ \\
\hline
\end{tabular}

This information enables us to hazard some guesses as to what the effect of giving B.C.G. to all the schoolchildren at the time of the first survey might have been. There were altogether 12 " attacks" in children between the ages of 5 and 14 (one child who later developed tuberculosis was not Mantoux tested at the time of the first survey). If B.C.G. had been given to the Mantoux-negative
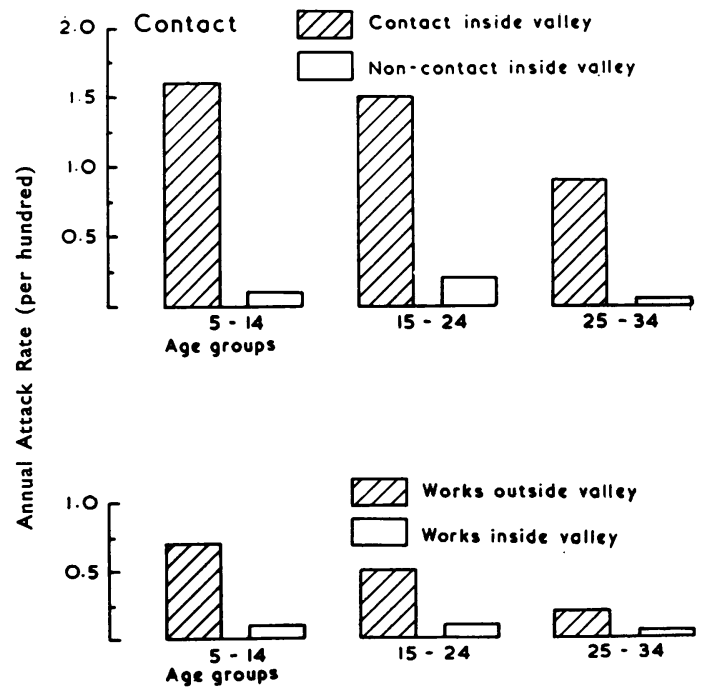

FIG. 7.-Relationship between known exposure to infection and attack rate of pulmonary tuberculosis in females in the Rhondda Fach. 
TABLE III

RELATIONSHIP BETWEEN WORKING INSIDE AND OUTSIDE THE VALLEY AND ATTACK RATE OF TUBERCULOSIS AMONGST WOMEN AND NON-MINERS LIVING IN THE RHONDDA FACH

\begin{tabular}{|c|c|c|c|c|c|c|c|}
\hline & \multirow[b]{2}{*}{ Age } & \multicolumn{3}{|c|}{$\begin{array}{c}\text { Working Outside } \\
\text { the Valley }\end{array}$} & \multicolumn{3}{|c|}{$\begin{array}{l}\text { Working Inside the } \\
\text { Valley }\end{array}$} \\
\hline & & No. & 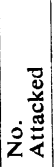 & 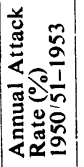 & No. & 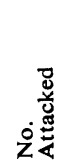 & 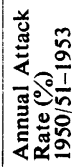 \\
\hline Women & $\begin{array}{r}5-14 \\
15-24 \\
25-34\end{array}$ & $\begin{array}{l}165 \\
501 \\
166\end{array}$ & $\begin{array}{l}3 \\
7 \\
1\end{array}$ & $\begin{array}{l}07 \\
0.5 \\
0.2\end{array}$ & $\begin{array}{l}1,578 \\
1,434\end{array}$ & $\begin{array}{l}5 \\
3 \\
2\end{array}$ & $\begin{array}{l}0.1 \\
0.1 \\
005\end{array}$ \\
\hline $\begin{array}{l}\text { Non-miners who } \\
\text { remained non- } \\
\text { miners } 1950-53\end{array}$ & $\begin{array}{r}5-14 \\
15-24 \\
25-34\end{array}$ & $\begin{array}{r}95 \\
348 \\
342\end{array}$ & $\begin{array}{l}1 \\
7 \\
3\end{array}$ & $\begin{array}{l}04 \\
0.8 \\
0.3\end{array}$ & $\begin{array}{l}1,498 \\
236 \\
183\end{array}$ & $\begin{array}{l}3 \\
5 \\
0\end{array}$ & $\begin{array}{ll} & 0.1 \\
0 & 8 \\
0 & 0\end{array}$ \\
\hline
\end{tabular}

TABLE IV

OVERCROWDING INDICES IN RHONDDA URBAN DISTRICT AND OTHER REPRESENTATIVE AREAS

\begin{tabular}{|c|c|c|c|}
\hline Area & & $\begin{array}{c}\text { Persons } \\
\text { per Room }\end{array}$ & $\begin{array}{l}\text { Percentage of } \\
\text { Persons at More } \\
\text { than } 2 \text { per Room }\end{array}$ \\
\hline 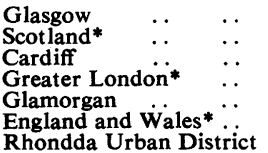 & $\begin{array}{ll}\cdots & \cdots \\
\cdots & \cdots \\
\cdots & \cdots \\
\cdots & \cdots \\
\cdots & \cdots\end{array}$ & $\begin{array}{l}1 \cdot 27 \\
1.04 \\
0 \cdot 77 \\
0.77 \\
0 \cdot 74 \\
0 \cdot 73 \\
0 \cdot 71\end{array}$ & $\begin{array}{r}24 \cdot 4 \\
15 \cdot 5 \\
2 \cdot 5 \\
1.7 \\
2 \cdot 2 \\
2 \cdot 2 \\
2 \cdot 2\end{array}$ \\
\hline
\end{tabular}

* Based on Census 1951, \% Sample Tables (General Register Office, 1952; General Registry Office, Edinburgh, 1952).

TABLE V

OVERCROWDING INDICES AMONGST THOSE ATTACKED BY PULMONARY TUBERCULOSIS COMPARED WITH A RANDOMLY SELECTED CONTROL GROUP OF THE SAME AGE AND SEX IN THE SAME VALLEY

\begin{tabular}{|c|c|c|c|c|c|}
\hline & & No. & $\begin{array}{l}\text { No. of } \\
\text { Rooms }\end{array}$ & $\begin{array}{c}\text { No. of } \\
\text { Persons }\end{array}$ & $\begin{array}{c}\text { No. of } \\
\text { Persons } \\
\text { per Room }\end{array}$ \\
\hline Females $\quad$. & $\begin{array}{l}\text { Attacked } \\
\text { Controls }\end{array}$ & $\begin{array}{l}22 \\
44\end{array}$ & $\begin{array}{l}126 \\
243\end{array}$ & $\begin{array}{l}126 \\
205\end{array}$ & $\begin{array}{l}1.00 \\
0.84\end{array}$ \\
\hline $\begin{array}{l}\text { Non-mining } \\
\text { males }\end{array}$ & $\begin{array}{l}\text { Attacked } \\
\text { Controls }\end{array}$ & $\begin{array}{l}19 \\
38\end{array}$ & $\begin{array}{l}105 \\
204\end{array}$ & $\begin{array}{r}90 \\
187\end{array}$ & $\begin{array}{l}0.86 \\
0.92\end{array}$ \\
\hline
\end{tabular}

TABLE VI

RELATIONSHIP BETWEEN THE RESULTS OF MANTOUX TESTING IN 1950/51 AND THE SUBSEQUENT ATTACK RATE OF TUBERCULOSIS AMONGST CHILDREN AGED 5-14 IN THE RHONDDA FACH

\begin{tabular}{c|c|c|c|c|c|c}
\hline & \multicolumn{2}{|c|}{ Mantoux Negative 1950/51 } & \multicolumn{2}{c}{ Mantoux Positive 1950/51 } \\
\hline Girls & $\begin{array}{c}\text { No. } \\
\overline{\text { Boys }}\end{array}$ & $\begin{array}{c}\text { No. } \\
\text { Attacked }\end{array}$ & $\begin{array}{c}\text { Annual Attack } \\
\text { Rate 1950 51- } \\
1953 \text { per \% }\end{array}$ & No. & $\begin{array}{c}\text { No. } \\
\text { Attacked }\end{array}$ & $\begin{array}{c}\text { Annual Attack } \\
\text { Rate 1950/51- } \\
1953 \text { per \% } \%\end{array}$ \\
\hline 4 & 1.7 & 298 & 4 & 5.2 \\
\hline
\end{tabular}

and if it had been completely successful in preventing re-infection with tuberculosis (and there is no suggestion from the American work that this is so), six out of the 12 would have been prevented, a relatively satisfactory result. However, from a more general administrative angle, the reduction in the general attack rate of tuberculosis in the next two and a half years which can be expected by giving B.C.G. to Mantoux-negative schoolchildren is six of the total of 41 , or $15 \%$ reduction, a less satisfactory picture. it suggests that the giving of B.C.G. to Mantoux-negative schoolchildren can $\overrightarrow{\vec{A}}$ only be an adjunct to and never a substitute for iv the control of infection by case finding and admission to hospital.

The EfFect of Dust Exposure.-In the Pneumoconiosis Research Unit radiological classifcation of coalworkers' pneumoconiosis (Davies and Mann, 1949; Cochrane, Davies, and Fletcher, 1951), three categories of increasing abnormality in simple pneumoconiosis are recognized. These three categories correspond to increasing degrees of pulmonary disability (although the disability is always slight) with increasing periods of exposure to coal dust, and very probably to increasing amounts of dust retained in the lungs. By dividing the population of miners and ex-miners into groups according to the category of simple pneumoconiosis in their original radiographs, we should obtain groups with increasing amounts of coal dust in the lungs and thus be able to study the effect of this on the attack rate of tuberculosis.

To do this, however, we must make certain assumptions about the nature of progressive massive fibrosis. The shadows which appear on a background of category 2 and 3 simple pneumoconiosis are indistinguishable from the shadows of early 3 tuberculosis. They are termed progressive massive 음 fibrosis because it is known from experience that when they appear in lungs with simple pneumoconiosis the natural history of their development is $\vec{N}$ very different from that of tuberculosis. However, of there is considerable evidence, chiefiy pathological $N$ and epidemiological (Cochrane, 1954), that progres- N sive massive fibrosis is merely a tuberculous lesion modified by the presence of dust, and for the 0 purposes of the present discussion tuberculosis and progressive massive fibrosis have been considered $\stackrel{\mathscr{\rho}}{\rightarrow}$ together.

For the study of the effect of the amount of coal dust in the lungs on the attack rate of tuber- $\stackrel{\mathbb{D}}{\circ}$ culosis, there were available 4,308 miners and $\mathbb{D}$ ex-miners who had been radiographed in 1950-51 and had been found at that time to have no evidence of tuberculosis or P.M.F. and who were examined 
TABLE VII

MINERS AND EX-MINERS IN THE RHONDDA FACH RADIOGRAPHED IN 1950/51 AND RADIOGRAPHED AGAIN IN 1953 BY $X$-RAY CATEGORY AT TIME OF FIRST SURVEY

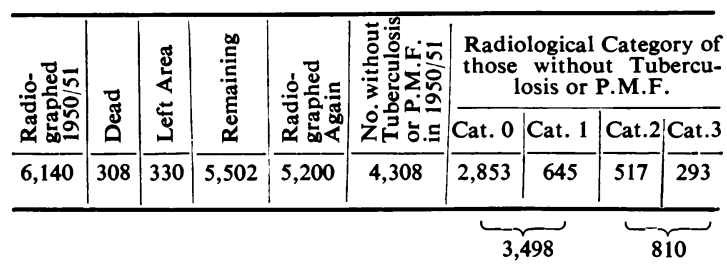

again in 1953. The derivation of this population is shown in Table VII, which also sets forth their pneumoconiosis radiological categories in 1950-51. In Table VIII these are divided into those with no evidence or with very slight evidence of simple pneumoconiosis (categories 0 and 1) and those with more advanced simple pneumoconiosis (categories 2 and 3); and the numbers in these two groups attacked by tuberculosis and P.M.F. between the two surveys are also shown. In Fig. 8, the attack rate of P.M.F. and tuberculosis among these men is compared with the attack rate of tuberculosis among non-miners. The differences between miners and ex-miners of categories 0 and 1 and the non-miners are very marked. The attack rate is not only very much lower amongst the miners and ex-miners, but has also shifted to the older age groups. The attack rate of shadows amongst those with category 0 and 1 is also very much lower than among those with category 2 and 3 simple pneumoconiosis. The differences in attack rate between non-miners on the one hand and miners and ex-miners on the other could theoretically be due to selection at the time of entry into mining. As we are dealing with a population of miners and ex-miners, there is no possibility of selection acting later. It is, however, difficult to see how the selection could actually work in order

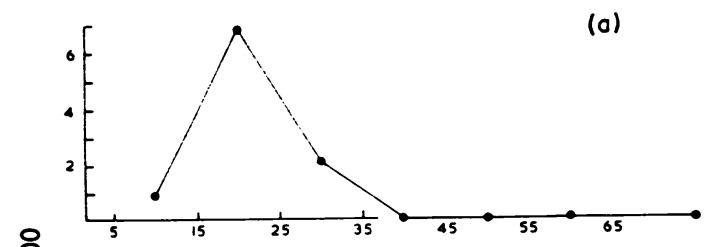

(b)
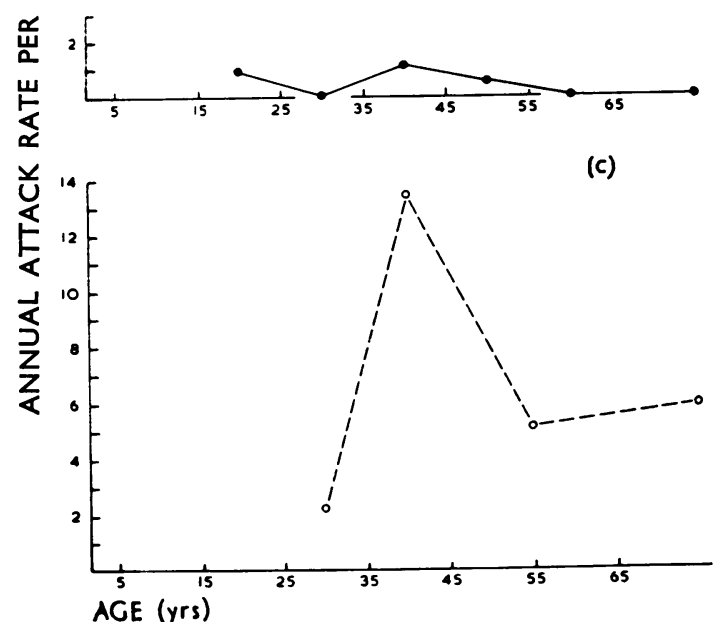

FIG. 8.-Annual attack rate of pulmonary tuberculosis and progressive massive fibrosis amongst males in the Rhondda Fach. Non-miners $(a)$, and miners and ex-miners with categories 0 and $1(b)$ and with categories 2 and $3(c)$ of simple pneumoconiosis, are shown separately.

to affect an attack rate so much later. The differences are almost certainly not due to the special post-survey condition in the Rhondda Fach, as similar though somewhat higher attack rates were found in another valley where there was no extra effort made to control tuberculosis (Cochrane and Miall, 1956). A further possible explanation is that the inhalation of coal dust affects the radiological attack rate of tuberculosis. This possibility

TABLE VIII

ANNUAL ATTACK RATE OF PULMONARY TUBERCULOSIS AND PROGRESSIVE MASSIVE FIBROSIS IN MALES IN THE RHONDDA FACH

\begin{tabular}{|c|c|c|c|c|c|c|c|c|c|c|c|c|c|c|c|}
\hline Age & $\begin{array}{l}\text { Non- } \\
\text { Miners }\end{array}$ & $\begin{array}{c}\text { No. } \\
\text { Attacked }\end{array}$ & $\begin{array}{l}\% / 00 \\
\text { per } \\
\text { Year }\end{array}$ & $\begin{array}{c}\text { Mine:s } \\
\text { and Ex- } \\
\text { Miners } \\
\text { Cat. 0 }\end{array}$ & $\begin{array}{c}\text { No. } \\
\text { Attacked }\end{array}$ & $\begin{array}{l}0 / 00 \\
\text { per } \\
\text { Year }\end{array}$ & $\begin{array}{l}\text { Miners } \\
\text { and Ex- } \\
\text { Miners } \\
\text { Cat. 1 }\end{array}$ & $\begin{array}{c}\text { No. } \\
\text { Attacked }\end{array}$ & $\begin{array}{l}\% / 00 \\
\text { per } \\
\text { Year }\end{array}$ & $\begin{array}{l}\text { Miners } \\
\text { and Ex- } \\
\text { Miners } \\
\text { Cat. 0 } \\
\text { and } 1\end{array}$ & $\begin{array}{c}\text { No. } \\
\text { Attacked }\end{array}$ & $\begin{array}{l}0_{100} \\
\text { per } \\
\text { Year }\end{array}$ & $\begin{array}{l}\text { Miners } \\
\text { and Ex- } \\
\text { Miners } \\
\text { Cat. 2 } \\
\text { and } 3\end{array}$ & $\begin{array}{c}\text { No. } \\
\text { Attacked }\end{array}$ & $\begin{array}{l}0 / 00 \\
\text { per } \\
\text { Year }\end{array}$ \\
\hline $\begin{array}{l}5- \\
55- \\
25- \\
35- \\
45- \\
55- \\
65-\end{array}$ & $\begin{array}{r}1,725 \\
683 \\
543 \\
329 \\
150 \\
96 \\
36\end{array}$ & $\begin{array}{r}4 \\
12 \\
3\end{array}$ & $\begin{array}{l}0.9 \\
6 \cdot 8 \\
2 \cdot 1\end{array}$ & $\begin{array}{l}395 \\
597 \\
560 \\
585 \\
448 \\
268\end{array}$ & $\begin{array}{l}1 \\
1 \\
1\end{array}$ & $\begin{array}{l}1.0 \\
0.7 \\
0.7\end{array}$ & $\begin{array}{r}19 \\
126 \\
139 \\
158 \\
125 \\
78\end{array}$ & 1 & 28 & $\begin{array}{l}414 \\
723 \\
699 \\
743 \\
573 \\
346\end{array}$ & $\begin{array}{l}1 \\
2 \\
1\end{array}$ & $\begin{array}{l}0.9 \\
1 \cdot 1 \\
0.5\end{array}$ & $\begin{array}{r}15 \\
173 \\
258 \\
175 \\
124 \\
65\end{array}$ & $\begin{array}{l}1 \\
9 \\
4 \\
1\end{array}$ & $\left.\begin{array}{r}2.2 \\
13.4 \\
8.8 \\
5.9\end{array}\right\}$ \\
\hline Total & 3.562 & 19 & $2 \cdot 0$ & 2,853 & 3 & 04 & 645 & 1 & 0.6 & 3,498 & 4 & 0.4 & 810 & 15 & $7 \cdot 1$ \\
\hline
\end{tabular}


has already been discussed by one of us elsewhere (Cochrane, 1954). It should be emphasized that the reduction of the attack rate on categories 0 and 1 is independent of any assumptions about the nature of P.M.F.

\section{Discussion}

From the theoretical point of view the main interest of this work is technical. We can claim to be the first to measure the radiological attack rate of tuberculosis in a defined community. It achieves added interest in that we were able to confirm Springett's estimate. The most interesting point is probably the similarity between the male and female attack rates, suggesting that the lesions diagnosed in elderly males are the end-results of " attacks" in early adolescence which have remained quiescent for many years.

From the practical point of view, we have produced evidence about the relationship between age, sex, occupation, and infection and the attack rate of tuberculosis. Of these, infection appears to be the most important factor and the one most easily altered. The only logical first step towards the control of infection is to radiograph everyone, and in our small-scale attempt we did not find it particularly easy. The critical problem is how to persuade people to be radiographed. Home visiting is costly and it is often difficult to find suitable people to do the work when money is available. This problem has, however, apparently been solved in Norway, Iceland, and Australia by making radiography compulsory. The Medical Research Council's Sub-Committee on Mass Radiography deal with this rather less than adequately in their report (Medical Research Council, 1954). Their only reference is in the following phrase:"“... regular examination by M.M.R., which is voluntary and will always remain so. . . ."

Compulsory radiography in this country could, of course, be introduced only if adequate facilities, medical and surgical, were available for the immediate treatment and later rehabilitation of every "new" case, together with adequate financial assistance for families whose breadwinner was found to be suffering from tuberculosis. But such a situation could be realized now with little additional effort, and if it were, surely most seriously minded people would be prepared to sacrifice a little of their personal freedom in order to help in the elimination of tuberculosis.

\section{SUMMARY}

Using the data from the two Rhondda Fach surveys (1950-51 and 1953) the annual attack rate of pulmonary tuberculosis has been calculated and the influence of age, sex, contact, Mantoux status, overcrowding, and exposure to coal dust investigated. Age was found to affect this index similarly in both sexes. Significant differences in attack rate were found between those who were in contact with known infectious cases in the valley between the two surveys and those who had no such contact, and between those who lived in the valley and worked outside it and those who both lived and worked there. Exposure to coal dust appears to modify and postpone the attack rate.

This work was carried out under the general direction of the Rhondda Fach Scheme Advisory Committee, and we should like to express our thanks to them for their help, encouragement, and advice. They are not in any way responsible, however, for the views expressed by the authors in this paper.

We should particularly like to thank the other members of the epidemiological team at the Pneumoconiosis Research Unit, who not only played a major part in both surveys but also had enough energy left to work out the results; the M.M.R. team who worked with us during the two surveys; Dr. C. M. Fletcher, previously Director of the Unit; Dr. J. C. Gilson, the Director; Mr. P. D. Oldham, member of the Scientific Staff of the Pneumoconiosis Research Unit; Dr. J. Glyn Cox, Consultant in Chest Diseases, Pontypridd and Rhondda District, and his staff; the numerous officials of the National Coal Board and the National Union of Mine workers who assisted us in the surveys; the Cardiff Pneumoconiosis Medical Panel of the Ministry of Pensions and National Insurance and many others who lent us films; the Medical Officer of Health, Rhondda Urban District, and his department; and above all, the men and women of the Rhondda Fach without whose help this work would have been impossible.

\section{REFERENCES}

Cochrane, A. L. (1954). Brit. J. Tuberc., 48, 274.

Cox, J. G., and Jarman, T. F. (1952). Brit. med. J., 2, 843. -1 (1955). Ibid., 1, 371.

Davies, I., and Fletcher, C. M. (1951). Brit. J. industr. Med., 8, 244.

Daniels Miall, W. E. (1956). Brit. med. J., 1, 1193. Tuberculosis in Young Adults. Report on the Prophit Tuberculosis Tuberculosis in Young Adults. Report on the Prophit TuberculQsis Survey, 1935-1944, p. 141. Lewis, London.

Davies, I., and Mann, K. J. (1949). Proc. 9th Int. Congr. on Industr. Med., London, 1948. Wright, Bristol.

General Register Office (1952). Census, 1951, Great Britain. One Per Cent Sample Tables, Part I. H.M.S.O., London.

(1954). Census, 1951, England and Wales. County Report, Glamorganshire. H.M.S.O. London.

General Registry Office, Edinburgh (1952). Census, 1951. Report on the Fifteenth Census of Scotland. Vol. I, part 2. City of Glasgow. H.M.S.O., Edinburgh.

Medical Research Council (1954). Report of the Committee for Research on Social and Environmental Health, Sub-Committee on Mass Miniature Radiography. M.R.C. 53/687.

Myers, J. A., and Harrington, F. E. (1934). J. Amer. med. Ass., 103, 1530 .

Palmer, C. E., and Shaw, L. W. (1953). Amer. Rev. Tuberc., 68, 462. Pope, A.S., Sartwell, P. E., and Zacks, D. (1939). Amer. J. publ. Hlth, 29,1318

Springett, V. H. (1951). Brit. med. J., 2, 144.

Stein, L. (1952). Brit. J. soc. Med., 6, 1.

- (1954). Tubercle (Lond.), 35, 195.

Stewart, C. A. (1940). Amer. J. Dis. Child., 59, 1034. 